\title{
不同粒径聚苯乙烯微塑料和苯并(a)芘联合暴露影响 炎性因子的表达
}

\author{
徐雅雯, 朱军, 胡堇叶, 张展, 李否, 吴倩 ${ }^{*}$ \\ 南京医科大学公共卫生学院卫生检验学系, 南京 211166 \\ *联系人, E-mail: wuqian@njmu.edu.cn
}

2020-06-05 收稿, 2020-08-14 修回, 2020-08-14 接受, 2020-08-17 网络版发表

江苏省自然科学基金(BK20161571)、江苏省高校自然科学研究重大项目(16KJA330002)、江苏高校品牌专业建设工程资助项目 (PPZY2015A067)和江苏高校优势学科建设工程项目资助

\begin{abstract}
摘要 研究发现, 微塑料可吸附并富集持久性有机污染物, 吸附污染物后的微塑料生物毒性增强. 本文旨在探究不 同粒径聚苯乙烯微塑料(polystyrene microplastics, PS-MPs)联合苯并(a)萠(benzo(a)pyrene, BaP)暴露, 对成年斑马鱼 鳃和支气管相关细胞炎性细胞因子表达的影响. 以两种粒径的 PS-MPs $(0.5$ 和 $5 \mu \mathrm{m})$ 分别与 BaP联合暴露幼鱼 $7 \mathrm{~d}$ 、成 鱼 $14 \mathrm{~d}$ 和细胞 $48 \mathrm{~h}$. 使用 Real-time PCR测定不同暴露组炎性因子基因相对表达情况, 体视镜观察微塑料颗粒进入幼 鱼体内的情况，共聚焦显微镜观察微塑料颗粒进入细胞的情况. 结果发现，粒径为 0.5 和 $5 \mu \mathrm{m}$ 的PS-MPs均能进入幼 鱼体内; $0.5 \mu \mathrm{m}$ PS-MPs单独暴露时, $T N F-\alpha 、 I L-6$ 和 $I L-8$ 基因相对表达显著高于对照组; $5 \mu \mathrm{m}$ PS-MPs单独暴露时, $I F N-\gamma$ 基因相对表达显著高于对照组. BaP和 $0.5 \mu \mathrm{m}$ PS-MPs联合暴露时，成鱼鳃组织 $I F N-\gamma$ 、IL-6和 $I L-8$ 基因的相对 表达高于 $\mathrm{BaP}$ 单独暴露. 细胞实验结果表明, 仅 $0.5 \mu \mathrm{m}$ 的PS-MPs能进入两种细胞胞质中. 在人支气管上皮样细胞 HBE 中 $0.5 \mu \mathrm{m}$ PS-MPs组炎症因子 $T N F-\alpha 、 I L-6$ 和 $I L-8$ 基因相对表达均高于对照组. 在人支气管平滑肌细胞HBSMC 中 $0.5 \mu \mathrm{m}$ PS-MPs组炎性细胞因子 $T N F-\alpha 、 I L-8$ 和 $I L-1 \beta$ 的相对表达显著高于对照组. HBE细胞中 BaP分别与 $0.5 \mu \mathrm{m} /$ $5 \mu \mathrm{m}$ 微塑料联合暴露时, 均未发现明显的联合作用. HBSMC 细胞中 BaP和 $0.5 \mu \mathrm{m}$ PS-MPs联合暴露时, 对 $I F N-\gamma$ 和 $I L-$ 6 炎症因子的表达有显著的联合作用; 而 BaP和 $5 \mu \mathrm{m}$ PS-MPs联合暴露时, 有显著减弱 BaP促炎作用的趋势, 特别是 对 TNF- $\alpha$ 和IL-8炎症因子表达的影响. 由此推断, 粒径可能是影响微塑料生物摄取和累积的主要因素之一, $0.5 \mu \mathrm{m}$ 微 塑料因其易被细胞摄取, 故联合有机污染物暴露可加重炎症反应. 另外, 因 $5 \mu \mathrm{m}$ 微塑料末能进入细胞, 其对炎症反 应的影响仍需进一步探究.
\end{abstract}

关键词聚苯乙烯微塑料, 苯并(a)萠, 炎症, 斑马鱼, 细胞

微塑料指直径 $<5 \mathrm{~mm}$ 的塑料颗粒 ${ }^{[1]}$, 比表面积大和 疏水性的特点使其更容易吸附污染物, 能够作为许多 有害化学物质的载体, 产生复合毒性效应. 有报道, 微 塑料可以富集海洋环境中的有机污染物 ${ }^{[2]}$, 增强其在海 洋生物体内的生物效应，包括免疫反应、氧化应激反

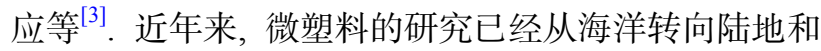

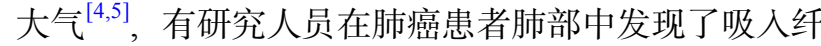
维素和塑料纤维 ${ }^{[6]}$, 说明微塑料可以通过大气“旅行”进 人呼吸道 ${ }^{[7]}$. 然而, 目前大气微塑料吸人及联合有机污 染物暴露对人体的健康风险研究较少，且致病机制尚 不明确, 因此开展相关研究至关重要.

随着经济的快速发展，燃煤取暖和汽车尾气排放

引用格式: 徐雅雯, 朱军, 胡堇叶, 等. 不同粒径聚苯乙烯微塑料和苯并(a)芘联合暴露影响炎性因子的表达. 科学通报, 2020, 65: 4281-4290 Xu Y W, Zhu J, Hu J Y, et al. Co-exposure to different sized polystyrene microplastics and benzo[a]pyrene affected inflammation in zebrafish and bronchialassociated cells (in Chinese). Chin Sci Bull, 2020, 65: 4281-4290, doi: 10.1360/TB-2020-0668 
等因素使得多环芳烃(polycyclic aromatic hydrocarbon, PAHs)成为城市空气中不容忽视的重点污染物之一. 流 行病学研究显示, PAHs暴露与儿童呼吸系统疾病如支 气管炎发生发展相关 ${ }^{[8]}$, 并影响成人肺功能 ${ }^{[9]}$. 多环芳 烃由细胞色素 $\mathrm{P} 450^{[10]}$ 代谢形成二醇-环氧化物, 与细胞 大分子共价结合, 诱导PAH-DNA加合物的形成, 其具 有细胞毒性、基因毒性, 可引起肺部炎症、甚至致

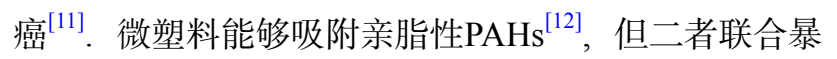
露对呼吸系统造成的潜在健康风险机理尚不清晰. 本 研究拟采用斑马鱼模型和支气管相关细胞模型对微塑 料颗粒联合苯并(a)萠暴露是否加重气道炎性反应进行 初步探究.

\section{1 材料和方法}

(i) 实验材料. 成年野生型斑马鱼购自南京尧顺 禹生物科技有限公司, 鱼龄为 6 个月. 斑马鱼饲料购自 山东升索渔用饲料研究中心. 人支气管上皮样细胞 (HBE) 和人支气管平滑肌细胞(HBSMC) 由南京医科 大学公共卫生学院储海燕副教授惠赠. 胎牛血清和高 糖培养基(DMEM)购于美国Gibco公司. 活细胞染色 液(Hoechst33342)和细胞膜红色苂光探针(DiI)购自上 海碧云天生物技术有限公司. 苯并(a)芘(Benzo[a]pyrene, $\geqslant 96 \%$, HPLC)购自美国Sigma公司 $(1 \mathrm{mg} / \mathrm{mL}$ 储 备液). MS-222试剂购自南京尧顺禹生物技术股份有 限公司. 聚苯乙烯绿色菼光微球购自天津倍思乐色谱 技术开发中心, 浓度 $10 \mathrm{mg} / \mathrm{mL}$ (工作浓度 $1 \mathrm{mg} / \mathrm{L}$ ), 直 径分别为 0.5 和 $5 \mu \mathrm{m}$, 最大发射波长为 $518 \mathrm{~nm}$, 最大激 发波长为 $488 \mathrm{~nm}$. DNA引物购自南京金斯瑞生物科技 公司.

(ii) 斑马鱼实验. 将成鱼随机分为6组: 对照组、 $1 \mathrm{mg} / \mathrm{L} 0.5 \mu$ m 微塑料组 ${ }^{[13 ~ 15]} 、 1 \mathrm{mg} / \mathrm{L} 5 \mu$ m 微塑料组、 $10 \mu \mathrm{g} / \mathrm{L} \mathrm{BaP}$ 组、 $\mathrm{BaP}$ 和 $0.5 \mu \mathrm{m}$ 微塑料联合暴露组、 $\mathrm{BaP}$ 和 $5 \mu \mathrm{m}$ 微塑料联合暴露组, 每组9条(雌鱼6条, 雄鱼 3 条). 在 $28^{\circ} \mathrm{C}$ 环境, $14: 10$ 明暗光周期条件下, 人工饲料 辅以丰年虫, 每日2次, 未通氧. 为防止塑料颗粒沉积, 培养液隔天更换一次, 共培养 $14 \mathrm{~d}$. 剖杀取两侧鰓组织, 液氮保存. 为观察微塑料在斑马鱼中的分布情况, 将成 年雌雄斑马鱼按 $1: 1$ 配对产卵, 暴露于加人上述浓度微 塑料的培养液中, 培育 $7 \mathrm{~d}$, 每天更换培养液, 第7天时 使用体视苂光显微镜SMZ18(Nikon, 日本)观察微塑料 进人幼鱼体内情况.

(iii) 细胞实验. HBE和HBSMC用含 $10 \%$ 胎牛血清
DMEM高糖完全培养基置于 $37^{\circ} \mathrm{C}, 5 \% \mathrm{CO}_{2}$ 培养箱中培 养. 细胞分为6组: 对照组、 $50 \mu \mathrm{g} / \mathrm{mL} \quad 0.5 \mu \mathrm{m}$ 微塑料 组、 $50 \mu \mathrm{g} / \mathrm{mL} 5 \mu \mathrm{m}$ 微塑料组、 $1 \mathrm{nmol} / \mathrm{L} \mathrm{BaP}$ 组、 $\mathrm{BaP}$ 和 $0.5 \mu \mathrm{m}$ 微塑料联合暴露组、 $\mathrm{BaP}$ 和 $5 \mu \mathrm{m}$ 微塑料联合 暴露组. $37^{\circ} \mathrm{C}$ 培养 $48 \mathrm{~h}$, 依据说明书方法分别将核与胞 质染色后, 使用激光共聚焦显微镜700B(Zeiss, Germany)拍照, 同时收集细胞, 液氮保存.

(iv) 炎性因子检测. 检测的炎症因子包括 $T N F-\alpha$ 、 $I F N-\gamma 、 I L-6 、 I L-8$ 和 $I L-1 \beta$. 冻存的斑马鱼鳃组织和细 胞, TRIzol(Invitrogen, 美国)法提取总RNA，核酸蛋白 分析仪(Thermo NanoDrop 2000, 美国)检测浓度. 反转录 使用试剂盒PrimeScript ${ }^{\mathrm{TM}}$ RT reagent Kit(TaKaRa Bio Inc, 日本), 具体操作根据说明书. PCR体系包含 $12.5 \mu \mathrm{L}$ $2 \times$ SYBR Green II Buffer(TaKaRa Bio Inc, 日本), $1 \mu \mathrm{L}$ 正 向引物 $(10 \mu \mathrm{mol} / \mathrm{L}), 1 \mu \mathrm{L}$ 反向引物 $(10 \mu \mathrm{mol} / \mathrm{L})$ 和 $2 \mu \mathrm{L}$ cDNA. PCR反应参数: $95^{\circ} \mathrm{C}$ 变性 $10 \mathrm{~min}$, 然后在 $95^{\circ} \mathrm{C}$ 变 性 $5 \mathrm{~s}, 60^{\circ} \mathrm{C}$ 退火延伸 $45 \mathrm{~s}$, 共 40 个循环. 每个循环在 $60^{\circ} \mathrm{C}$ 获得苂光数据. 采用LightCycler 96(Roche, 瑞士)进行实 时定量苂光PCR检测分析. 引物设计使用Primer Premier 5.0, 如表1所示. GAPDH作为细胞基因表达内参, $\beta$-catin作为斑马鱼基因表达内参, 设置 3 个平行. 采用

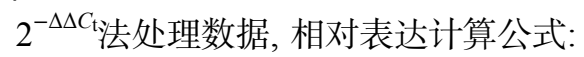

$\Delta C_{\mathrm{t}}=$ Mean $C_{\mathrm{t}(\text { 测量基因 })}-$ Mean $C_{\mathrm{t}(G A P D H \text { 基因 })}$;

$\Delta \Delta C_{\mathrm{t}}=\Delta C_{\mathrm{t}(\text { 实验组 })}-\Delta C_{\mathrm{t} \text { (对照组) }}$

( V ) 数据统计分析. 采用 $t$ 检验比较各暴露组与对 照组之间差异性; 单因素方差分析比较各暴露组间差 异性, $P<0.05$ 具有统计学意义. 采用GraphPad Prism 6.0 软件分析和作图.

\section{2 结果}

\section{1 斑马鱼幼鱼体内微塑料分布情况}

如图1所示, 粒径为 0.5 和 $5 \mu \mathrm{m}$ 的微塑料颗粒均能进 人幼鱼体内, 实验组的幼鱼胃肠道内可观察到绿色苂 光颗粒; 对照组的幼鱼体内无微塑料颗粒.

\section{2 微塑料暴露影响成年斑马鱼鳃中炎性细胞因子 的相对表达}

如图2所示, $0.5 \mu \mathrm{m}$ 微塑料组的 $T N F-\alpha 、 I L-6$ 和 $I L-8$ 基因相对表达显著高于对照组； $5 \mu \mathrm{m}$ 微塑料组的 $I F N-\gamma$ 基因相对表达显著高于对照组. 
表 1 PCR引物序列

Table 1 PCR primer sequences

\begin{tabular}{ccc}
\hline 基因名称 & 上游引物序列 & 下游引物序列 \\
\hline Danio rerio $\beta$-actin & 5'-GTGACCGTCCAGAAATGCTT-3' & 5'-CACCAGGACCACTCCCTAAA-3' \\
$T N F-\alpha$ & 5'-CAAAACATTCTTCGGGGTGT-3' & 5'-ACTCTCACTGCATCGGCTTT-3' \\
$I F N-\gamma$ & 5'-CTTCAGACAACCAGCGCATA-3' & 5'-CAGCATTCCTTCAAGCAACA-3' \\
$I L-6$ & 5'-TCTGCCACACCTGAAGACAG-3' & 5'-GAAGCCGAGTTAGGACGATG-3' \\
$I L-8$ & 5'-CTACCGAGACGTGGGTGATT-3' & 5'-CGTGTTGTGAGGAGGGAAGT-3' \\
Homo sapiens GAPDH & 5'-GAAGGTGAAGGTCGGAGTC-3' & 5'-GAAGATGGTGATGGGATTTC-3' \\
$T N F-\alpha$ & 5'-CCCTCACACTCACAAACCAC-3' & 5'-ACAAGGTACAACCCATCGGC-3' \\
$I F N-\gamma$ & 5'-GCGCCAAGCATTCAATGAGC-3' & 5'-ATCTCTTCCCCACCCCGAAT-3' \\
$I L-6$ & 5'-CCTTCGGTCCAGTTGCCTTCTCCCT-3' & 5'-GGGCTGAGATGCCGTCGAGGATGTA-3' \\
$I L-8$ & 5'-CCACCGGAAGGAACCATCTC-3' & 5'-TTCCTTGGGGTCCAGACAGA-3' \\
\hline
\end{tabular}

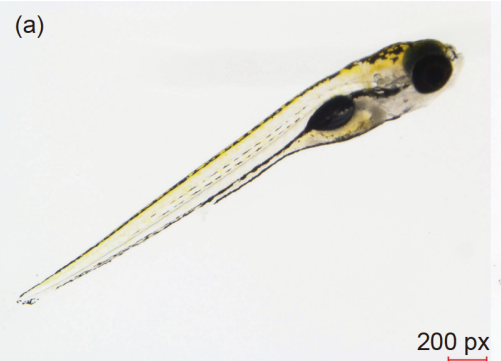

(d) (b)

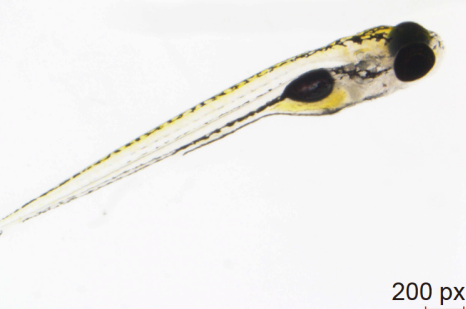

(c)

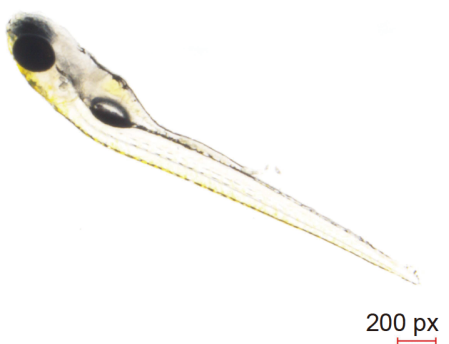

(e)

(f)

图 1 体视苂光显微镜下斑马鱼幼鱼中微塑料分布. 绿色苂光颗粒为聚苯乙烯塑料微粒. (a) (c) 正常光照片; (d) (f) 最大发射波长 $518 \mathrm{~nm}$ 时的 苂光照片. (a), (d) 对照组; (b), (e) $0.5 \mu$ m微塑料组; (c), (f) $5 \mu$ m微塑料组

Figure 1 PS-MPs distribution in zebrafish by stereoscopic fluorescence microscope. The green fluorescent particles are PS-MP particles. (a)-(c) Normal photos; (d)-(f) fluorescence photos with the maximum emission wavelength of $518 \mathrm{~nm}$. (a), (d) Control group; (b), (e) $0.5 \mu \mathrm{m}$ MP group; (c), (f) $5 \mu \mathrm{m}$ MP group

\subsection{BaP和微塑料联合暴露影响成年斑马鱼鳃中炎 性细胞因子的相对表达}

如图3所示, $\mathrm{BaP}$ 与 $0.5 \mu \mathrm{m}$ 微塑料联合暴露组 $I F N-$ $\gamma 、 I L-6$ 和 $I L-8$ 基因的表达显著高于 $\mathrm{BaP}$ 单独暴露组; $\mathrm{BaP} 5 \mu \mathrm{m}$ 微塑料联合暴露组仅 $I L-6$ 基因的表达显著 高于 $\mathrm{BaP}$ 单独暴露组, 提示 $\mathrm{BaP}$ 和 $0.5 \mu \mathrm{m}$ 微塑料联合暴
露时产生明显的联合作用.

\section{4 微塑料的粒径影响HBE细胞和HBSMC 细胞 摄取}

如图4所示，粒径为 $0.5 \mu \mathrm{m}$ 的微塑料颗粒被摄人并 分布在两种细胞胞质中; 粒径为 $5 \mu \mathrm{m}$ 的微塑料颗粒未进 

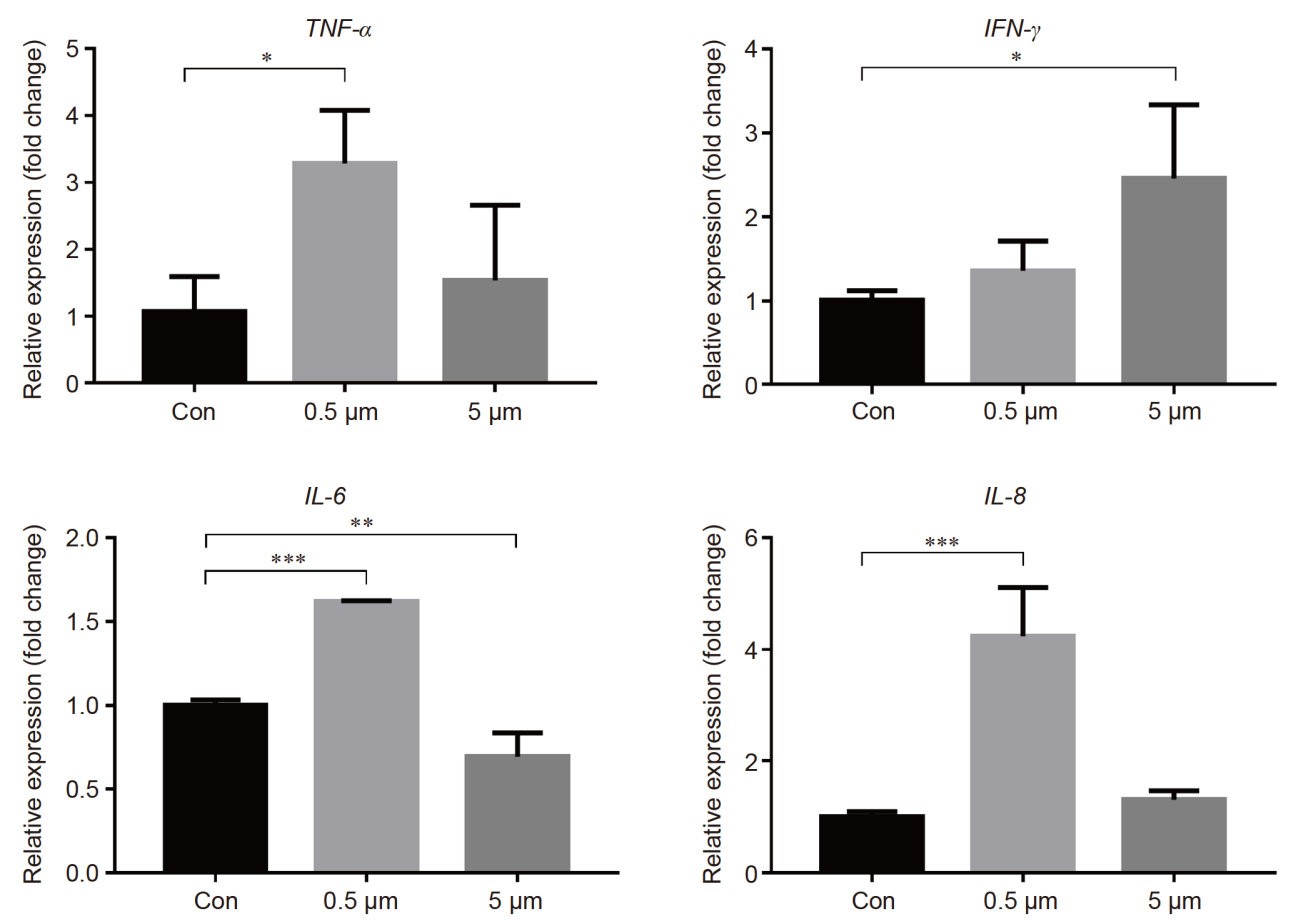

图 2 不同粒径微塑料暴露对斑马鱼鰓炎性细胞因子基因相对表达的影响. $* P<0.05, * * P<0.01, * * * P<0.001$

Figure 2 Effects of PS-MPs exposure with different particle sizes on relative expression of inflammatory factors in zebrafish gill. $* P<0.05, * * P<$ $0.01,{ }^{* * *} P<0.001$
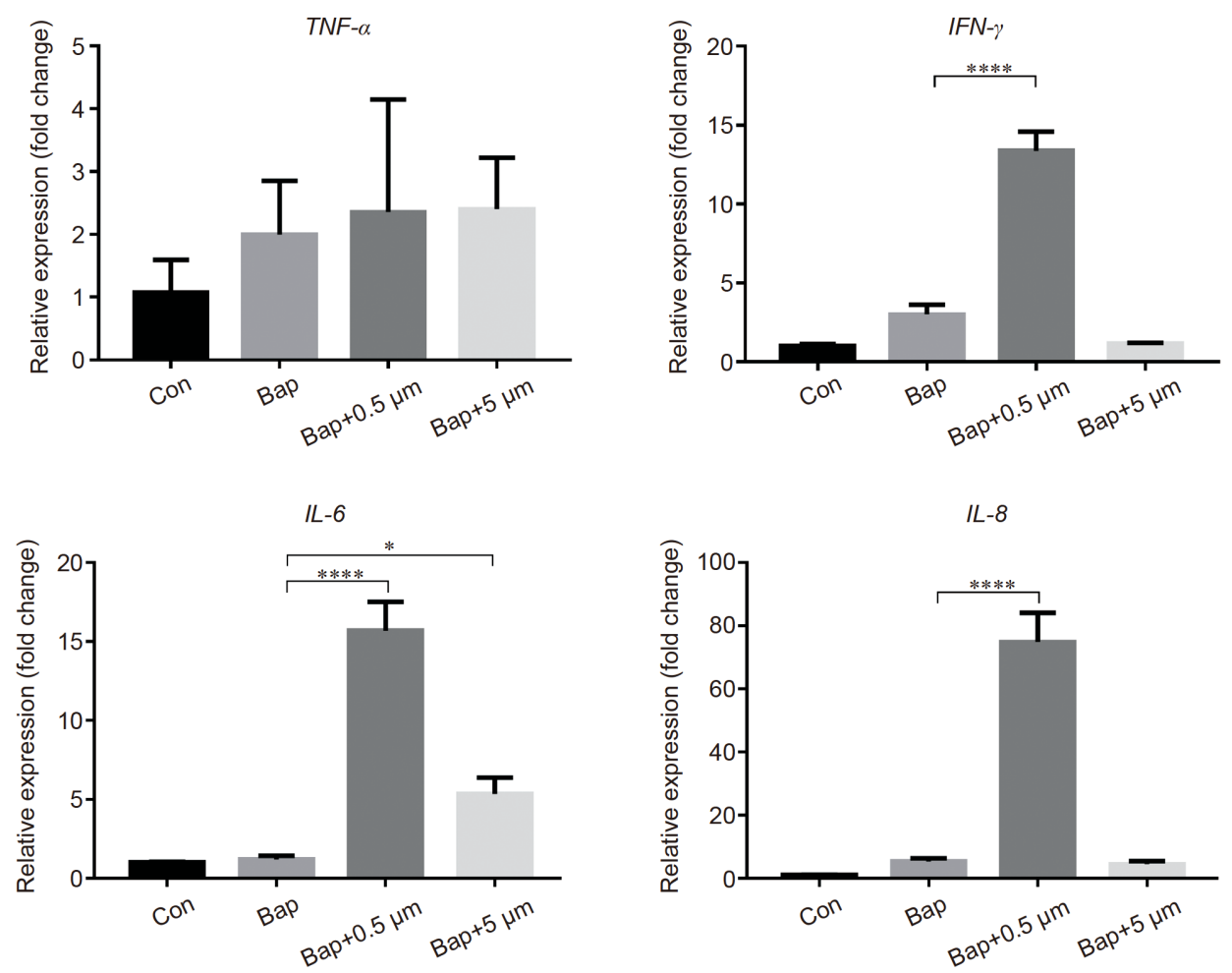

图 $3 \mathrm{BaP}$ 与微塑料联合暴露对斑马鱼鳃中炎性细胞因子基因相对表达的影响. $* P<0.05, * * * * P<0.0001$

Figure 3 Effects of co-exposure with PS-MPs and $\mathrm{BaP}$ on relative expression of inflammatory factors in zebrafish gills. ${ }^{*} P<0.05$, $* * * * P<0.0001$ 

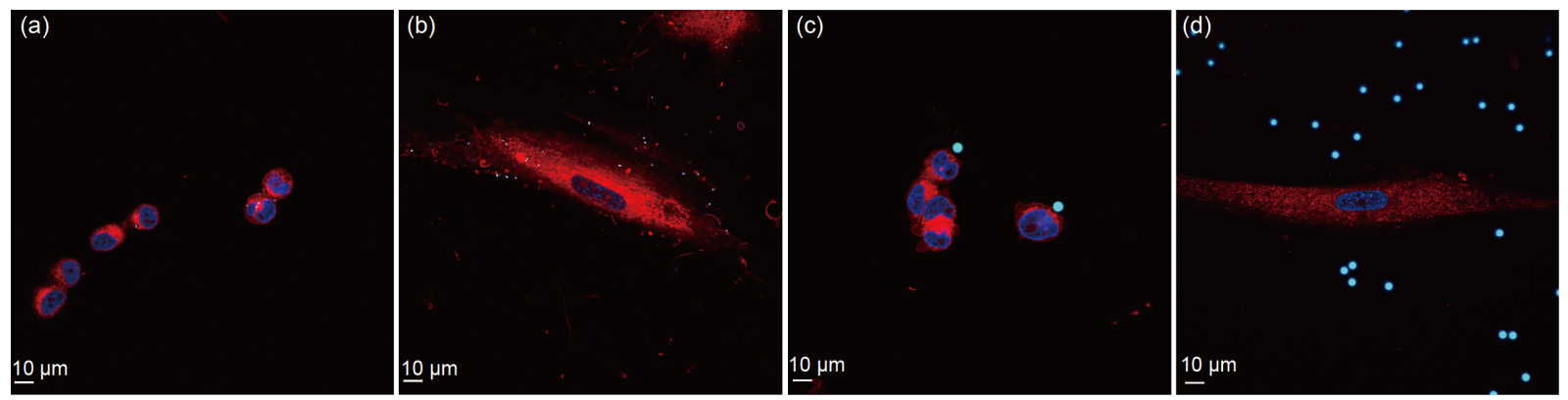

图 4 激光共聚焦显示微塑料在HBE细胞和HBSMC细胞内的分布情况. 镜下胞质呈红色、核呈蓝色、聚苯乙烯微塑料为圆形绿色苂光颗粒. (a) HBE细胞 $0.5 \mu$ m微塑料组; (b) HBSMC细胞 $0.5 \mu \mathrm{m}$ 微塑料组; (c) HBE细胞 $5 \mu \mathrm{m}$ 微塑料组; (d) HBSMC细胞 $5 \mu \mathrm{m}$ 微塑料组

Figure 4 The distribution of PS-MPs in HBE and HBSMC cells by laser confocal microscopy. The cytoplasm is red. The nucleus is blue. PS-MP are green fluorescent particles under laser confocal microscopy. (a) $0.5 \mu \mathrm{m}$ MP in HBE; (b) $0.5 \mu \mathrm{m}$ MP in HBSMC; (c) $5 \mu \mathrm{m}$ MP in HBE; (d) $5 \mu \mathrm{m}$ MP in HBSMC

人细胞内, 说明粒径的尺寸影响细胞摄取微塑料颗粒.

\section{5 微塑料暴露影响HBE细胞和HBSMC细胞中 炎性细胞因子的相对表达}

如图5所示, 在HBE细胞中, $0.5 \mu \mathrm{m}$ 微塑料组炎症因 子 $T N F-\alpha 、 I L-6$ 和 $I L-8$ 基因相对表达均高于对照组．如 图6所示, 在HBSMC细胞中, $0.5 \mu \mathrm{m}$ 微塑料组炎性细胞 因子 $T N F-\alpha 、 I L-8$ 和 $I L-1 \beta$ 的相对表达显著高于对照组.

\subsection{BaP和微塑料联合暴露影响HBE细胞和HBSMC 细胞中炎性细胞因子的相对表达}

如图7所示, 在 $\mathrm{HBE}$ 细胞中BaP分别和 $0.5 \mu \mathrm{m} / 5 \mu \mathrm{m}$
微塑料联合暴露组, 均未发现明显的联合作用, 不论是 上调表达的 $T N F-\alpha$ 和 $I L-8$ 炎症因子，还是下调表达的 $I F N-\gamma 、 I L-6$ 和 $I L-1 \beta$ 炎症因子．如图8所示，在HBSMC 细胞中, $\mathrm{BaP}$ 和 $0.5 \mu \mathrm{m}$ 微塑料联合暴露组对 $I F N-\gamma$ 和 $I L-6$ 炎症因子的表达有显著的联合作用. 而BaP和 $5 \mu \mathrm{m}$ 微塑 料联合暴露组有显著减弱 $\mathrm{BaP}$ 促炎作用的趋势, 特别是 对 $T N F-\alpha$ 和 $I L-8$ 炎症因子表达的影响.

\section{3 讨论}

在斑马鱼幼鱼实验中我们观察到粒径分别为 0.5 和 $5 \mu \mathrm{m}$ 的聚苯乙烯微塑料在鱼体内的分布和积累情况与 相关文献结果基本一致。例如，Lei等人 ${ }^{[16]}$ 研究使用的
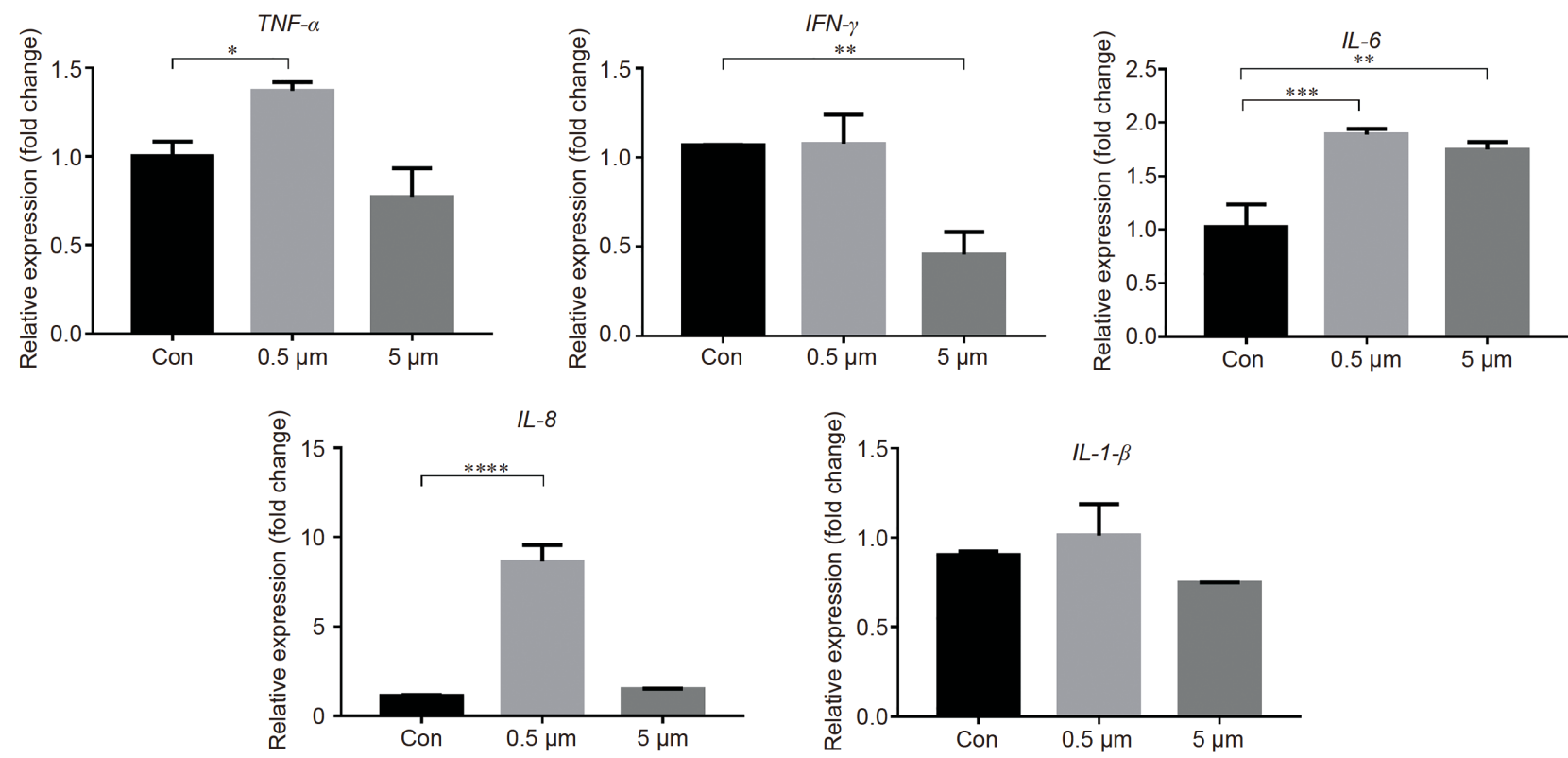

图 5 不同粒径微塑料暴露对 $\mathrm{HBE}$ 细胞中炎性细胞因子基因相对表达的影响. $* P<0.05, * * P<0.01, * * * P<0.001, * * * * P<0.0001$

Figure 5 Effects of PS-MPs exposure with different particle sizes on relative expression of inflammatory factors in $\mathrm{HBE}$ cells. $* P<0.05, * * P<0.01$, $* * * P<0.001,{ }^{* * * *} P<0.0001$ 

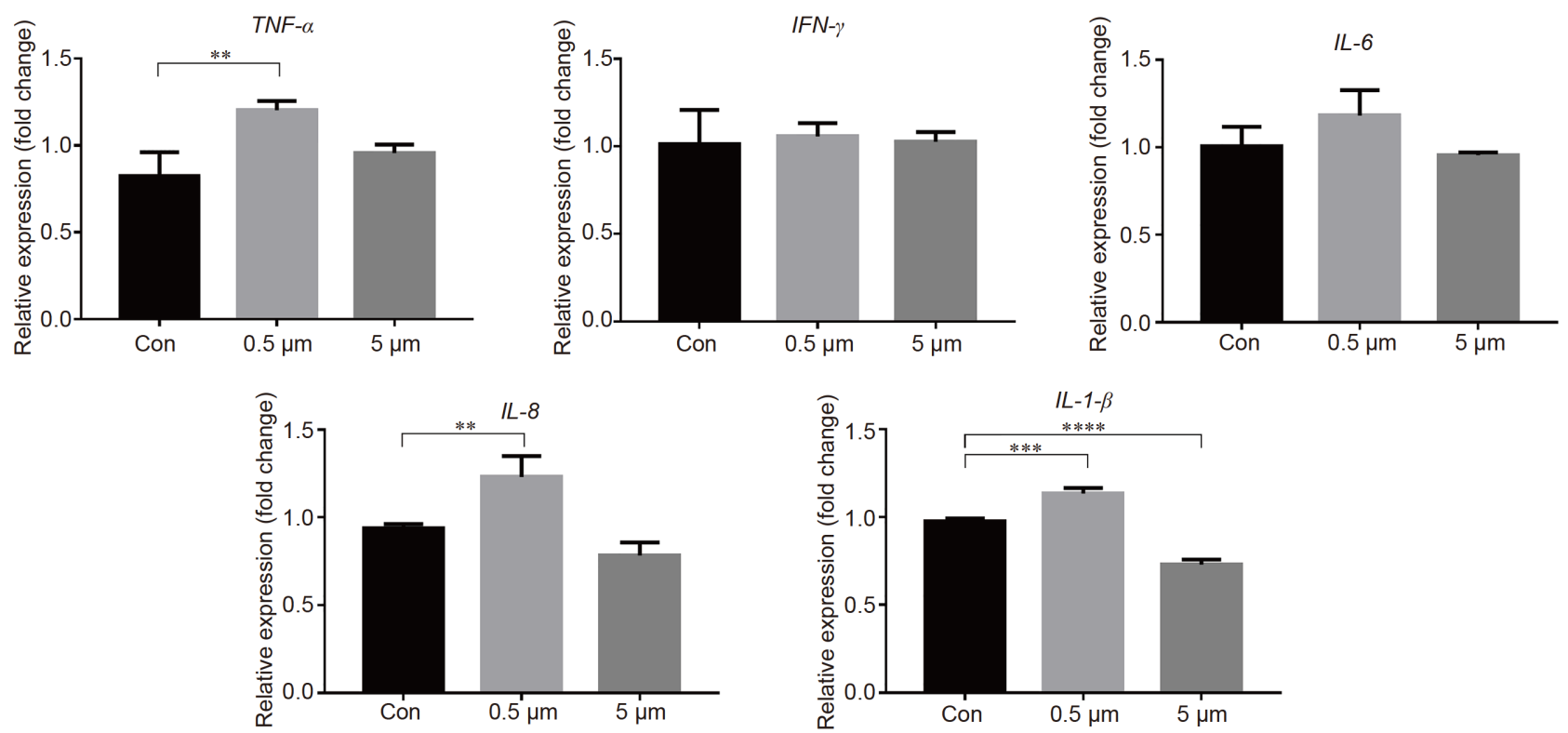

图 6 不同粒径微塑料暴露对HBSMC细胞中炎性细胞因子基因相对表达的影响. $* * P<0.01, * * * P<0.001, * * * * P<0.0001$

Figure 6 Effects of PS-MPs exposure with different particle sizes on relative expression of inflammatory factors in $\operatorname{HBSMC}$ cells. ${ }^{* *} P<0.01, * * * P<$ $0.001, * * * * P<0.0001$
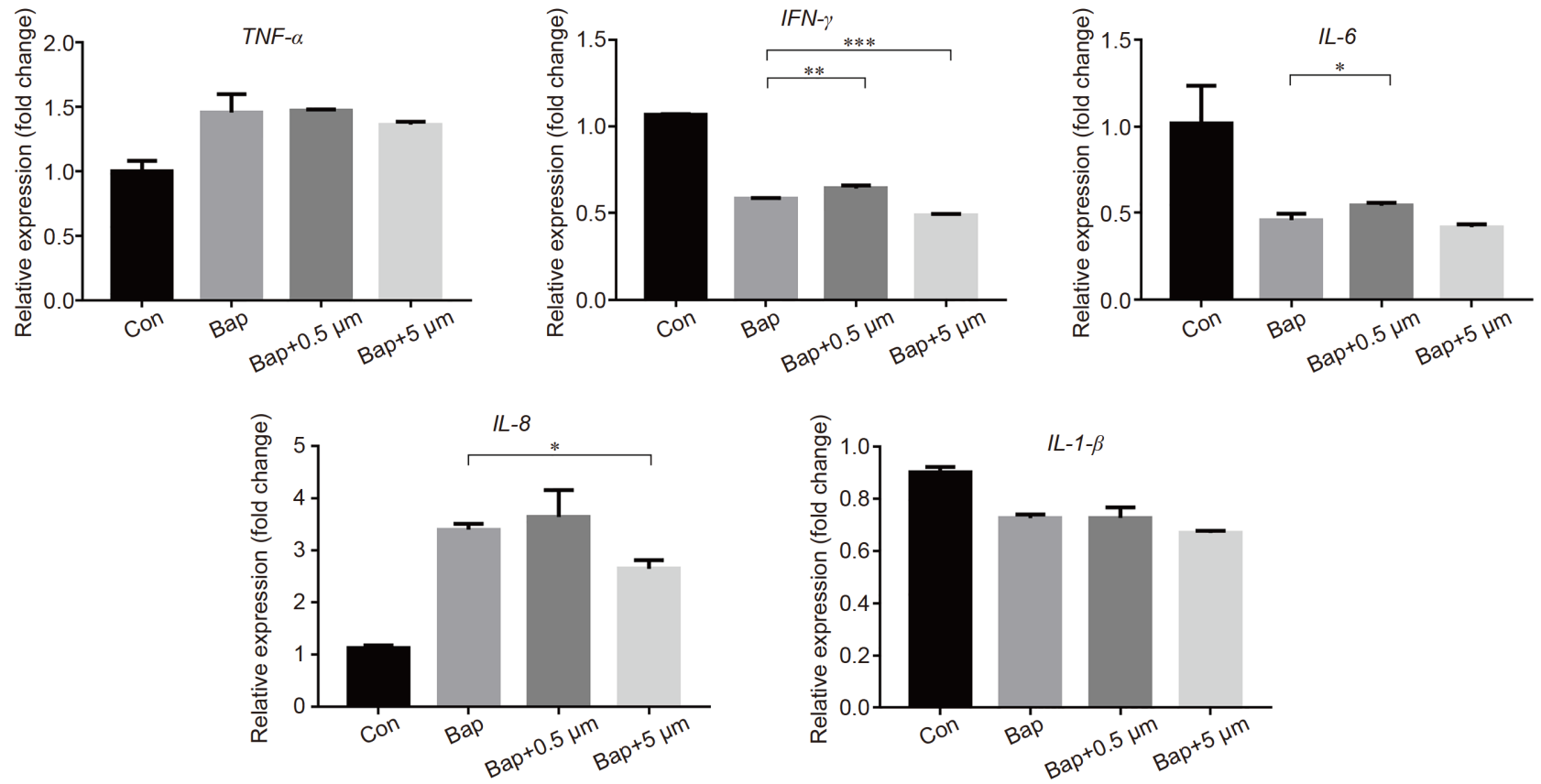

图 $7 \mathrm{BaP}$ 与微塑料联合暴露对 $\mathrm{HBE}$ 细胞中炎性细胞因子基因相对表达的影响. $* P<0.05, * * P<0.01, * * * P<0.001$

Figure 7 Effects of co-exposure with PS-MPs and $\mathrm{BaP}$ on relative expression of inflammatory factors in HBE cells. ${ }^{*} P<0.05, * * P<0.01, * * * P<$ 0.001

0.1 、 1 和 $5.0 \mu \mathrm{m}$ 微塑料颗粒均能进入斑马鱼体内. Qiao 等人 ${ }^{[17]}$ 的研究显示, $5 \mu \mathrm{m}$ 的微塑料能够进入斑马鱼肠 道. Batel等人 ${ }^{[6]}$ 的实验结果表明, $1 \sim 5 \mu \mathrm{m}$ 粒径微塑料颗
粒在进人成年斑马鱼鳃中 6 和 $24 \mathrm{~h}$ 后, 大多数微塑料颗 粒附着在鳃黏液层的纤维上, 并不断被排出.

斑马鱼作为现代病理学、免疫学等研究中常用的 

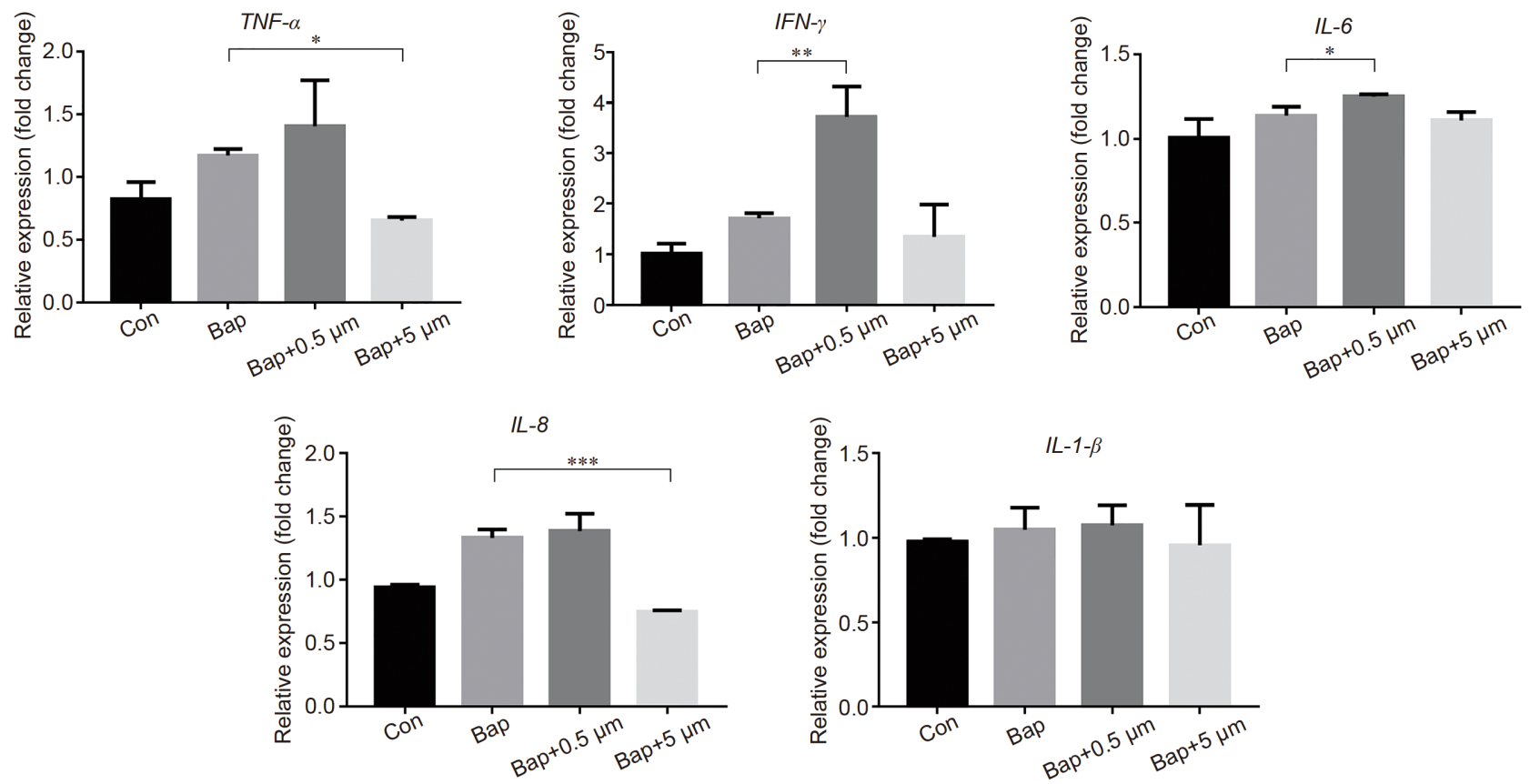

图 $8 \mathrm{BaP}$ 与微塑料联合暴露对HBSMC细胞中炎性细胞因子基因相对表达的影响. ${ }^{*} P<0.05, * * P<0.01, * * * P<0.001$

Figure 8 Effects of co-exposure with PS-MPs and BaP on relative expression of inflammatory factors in HBSMC cells. $* P<0.05$, $* * P<0.01, * * * P$ $<0.001$

模式生物 ${ }^{[18]}$ ，与人类基因高度相似并具有高度保守的 疾病信号转导通路 ${ }^{[19]}$. 斑马鱼的先天和适应性免疫系 统，包括巨噬细胞、粒细胞、Th1、Th2标记的T细胞 和 $\mathrm{B}$ 细胞 ${ }^{[20]}$, 肺部疾病相关的炎症细胞也与人类高度 相似 ${ }^{[21,22]}$. 斑马鱼鳃上皮的免疫细胞和平滑肌细胞分 布在鳃板上, 并有黏液覆盖 ${ }^{[23]}$, 结构与哺乳动物的呼吸 道相似, 具有相同的气体交换功能, 是研究肺部炎症的 良好模型.

在斑马鱼实验中我们发现, $0.5 \mu \mathrm{m}$ 微塑料组的 $T N F-\alpha 、 I L-6$ 和 $I L-8$ 基因相对表达显著高于对照组; $\mathrm{BaP}$ 与 $0.5 \mu \mathrm{m}$ 微塑料联合暴露组 $I F N-\gamma 、 I L-6$ 和 $I L-8$ 基因 的表达显著高于BaP单独暴露组, 产生了明显的联合作 用. 细胞实验中, 在HBSMC细胞中, $0.5 \mu \mathrm{m}$ 微塑料组炎 性细胞因子 $T N F-\alpha 、 I L-8$ 、和 $I L-1 \beta$ 的相对表达显著高 于对照组; $\mathrm{BaP}$ 和 $0.5 \mu \mathrm{m}$ 微塑料联合暴露组对 $I F N-\gamma$ 和 $I L-6$ 炎症因子的表达有显著的联合作用，而 $\mathrm{BaP}$ 和 $5 \mu \mathrm{m}$ 微塑料联合暴露组有显著减弱对 $T N F-\alpha$ 和 $I L-8$ 炎症因 子表达的影响. 我们认为, 粒径可能是影响微塑料通过 不同机制引发细胞炎症反应的因素之一：5 $\mu \mathrm{m}$ 的聚苯 乙烯微塑料颗粒无法进入细胞质中，仅在胞外造成机 械损伤, 引起细胞炎症反应; 粒径为 $0.5 \mu \mathrm{m}$ 的微塑料被 摄人胞内同时带人吸附于表面的 $\mathrm{BaP}^{[11]}$, 破坏细胞生理
功能引发炎症并加重BaP对细胞的毒作用, 如促进炎性 细胞因子的表达升高. 但Liu等人 ${ }^{[24]}$ 的研究结果显示, 纳米聚苯乙烯微塑料颗粒尺寸的减小对吸附多环芳烃 没有明显影响. 本研究选择了微米级的微塑料, 其中小 粒径的为 $0.5 \mu \mathrm{m}$, 对 $\mathrm{BaP}$ 的富集作用是否较粒径为 $5 \mu \mathrm{m}$ 的微塑料颗粒更强, 有待进一步研究.

本研究主要检测了炎性细胞因子 $T N F-\alpha 、 I F N-\gamma$ 、 $I L-1 \beta 、 I L-6$ 和 $I L-8$ 的相对表达情况. 在斑马鱼和细胞模 型中，BaP和PS-MPs联合暴露时炎症因子 $I L-6 、 I L-8$ 表 达的变化相对稳定. 在炎症过程中, 肿瘤坏死因子 (tumor necrosis factor, $T N F$ )、白细胞介素(interleukin, $I L$ ) 和干扰素家族(interferon, $I F N$ )等起主要作用. 斑马鱼炎 症因子 $I L-8$ 与人类的具有高度同源性 ${ }^{[25,26]}$. $I L-8$ 由巨噬 细胞和上皮细胞等分泌，与白细胞上的趋化因子受体 结合并激活这些受体，诱导特异性细胞内信号传导级 联, 快速募集中性粒细胞 ${ }^{[27,28]}$, 参与机体局部急性炎症 初期过程 ${ }^{[29]}$, 是各种炎症细胞所表达和释放的第一个 信号 ${ }^{\left[{ }^{[0,31]}\right.}$. IL-6主要由单核巨噬细胞、Th2细胞、血管 内皮细胞产生，诱导 $\mathrm{B}$ 细胞分化和产生抗体，诱导 $\mathrm{T}$ 细 胞活化增殖、分化, 参与机体免疫应答, 是炎性反应的 促发剂 ${ }^{[32]}$. 我们推测, 微塑料颗粒吸附 $\mathrm{BaP}$ 后进人呼吸 道, 通过支气管上皮细胞附着、摄人, 进人肺泡并聚集 
在终末细支气管中, 引起肺巨噬细胞M1极化, 而 $I L-6$ 可 通过对巨噬细胞的抑制作用进一步抑制 Th1、Treg细 胞的分化, 促进Th2、Th17细胞的分化 ${ }^{[33]}$, 加重气道炎 症反应.

另外, 微塑料很大一部分来自微纤维. 在生活中, 以化纤为原料的物品非常普遍, 如衣物、地毯等. 衣物 摩擦或在地毯上行走，会释放出微纤维进而形成微塑 料. 呼吸途径摄入微塑料可能更为直接, 摄人量也非常 大，可能与饮食摄人量相当，不容忽视. Dris等人 ${ }^{[34]}$ 报 道, 起居室或办公室内空气纤维类微塑料沉降通量可 达 $1.60 \times 10^{3} \sim 1.10 \times 10^{4}$ 个 $/\left(\mathrm{cm}^{3} \mathrm{~d}\right)$. 本研究中仅采用聚苯 乙烯微塑料及海洋环境中微塑料毒性作用浓度来分析
其生物效应具有一定局限性，与实际大气环境中微塑 料种类和浓度可能不同，未来应聚焦研究大气环境不 同种类、浓度和粒径的微塑料暴露的生物积累效应及 联合持久性有机污染物后对人体的毒性效应.

\section{4 结论}

微塑料的粒径可能是影响生物摄取和累积的主要 因素之一, 联合有机污染物暴露可加重炎症反应. 微塑 料作为新兴的环境污染物之一，其自身和吸附其他环 境污染物对人体健康产生的潜在危害值得关注. 研究 微塑料和大气污染物相互作用效应对探索其相互作用 的机制和揭示微塑料危害人体呼吸系统有重要意义.

\section{参考文献}

1 Andrady A L. Microplastics in the marine environment. Mar Pollut Bull, 2011, 62: 1596-1605

2 Pauly J L, Stegmeier S J, Allaart H A, et al. Inhaled cellulosic and plastic fibers found in human lung tissue. Cancer Epidemiol Biomarkers Prev, 1998, 7: 419-428

3 Kim Y, Jeong J, Lee S, et al. Identification of adverse outcome pathway related to high-density polyethylene microplastics exposure: Caenorhabditis elegans transcription factor RNAi screening and zebrafish study. J Hazard Mater, 2020, 388: 121725

4 Liu M, Lu S, Song Y, et al. Microplastic and mesoplastic pollution in farmland soils in suburbs of Shanghai, China. Environ Pollut, 2018, 242: $855-862$

5 Allen S, Allen D, Moss K, et al. Examination of the ocean as a source for atmospheric microplastics. PLoS One, 2020, 15: e0232746

6 Batel A, Borchert F, Reinwald H, et al. Microplastic accumulation patterns and transfer of benzo[a]pyrene to adult zebrafish (Danio rerio) gills and zebrafish embryos. Environ Pollut, 2018, 235: 918-930

7 Wright S L, Kelly F J. Plastic and human health: A micro issue? Environ Sci Technol, 2017, 51: 6634-6647

8 Hertz-Picciotto I, Baker R J, Yap P S, et al. Early childhood lower respiratory illness and air pollution. Environ Health Perspect, 2007, 115: 15101518

9 Cakmak S, Hebbern C, Cakmak J D, et al. The influence of polycyclic aromatic hydrocarbons on lung function in a representative sample of the Canadian population. Environ Pollut, 2017, 228: 1-7

10 Shimada T, Fujii-Kuriyama Y. Metabolic activation of polycyclic aromatic hydrocarbons to carcinogens by cytochromes P450 1A1 and $1 \mathrm{~B} 1$. Cancer Sci, 2004, 95: 1-6

11 Pratt M M, John K, MacLean A B, et al. Polycyclic aromatic hydrocarbon (PAH) exposure and DNA adduct semi-quantitation in archived human tissues. Int J Environ Res Public Health, 2011, 8: 2675-2691

12 Batel A, Linti F, Scherer M, et al. Transfer of benzo[a]pyrene from microplastics to Artemia nauplii and further to zebrafish via a trophic food web experiment: CYP1A induction and visual tracking of persistent organic pollutants. Environ Toxicol Chem, 2016, 35: 1656-1666

13 Wegner A, Besseling E, Foekema E M, et al. Effects of nanopolystyrene on the feeding behavior of the blue mussel (Mytilus edulis L.). Environ Toxicol Chem, 2012, 31: 2490-2497

$14 \mathrm{Lu} \mathrm{Y}$, Zhang Y, Deng Y, et al. Uptake and accumulation of polystyrene microplastics in zebrafish (Danio rerio) and toxic effects in liver. Environ Sci Technol, 2016, 50: 4054-4060

15 Liu Z, Cai M, Yu P, et al. Age-dependent survival, stress defense, and AMPK in Daphnia pulex after short-term exposure to a polystyrene nanoplastic. Aquat Toxicol, 2018, 204: 1-8

16 Lei L, Wu S, Lu S, et al. Microplastic particles cause intestinal damage and other adverse effects in zebrafish Danio rerio and nematode Caenorhabditis elegans. Sci Total Environ, 2018, 619-620: 1-8

17 Qiao R, Sheng C, Lu Y, et al. Microplastics induce intestinal inflammation, oxidative stress, and disorders of metabolome and microbiome in zebrafish. Sci Total Environ, 2019, 662: 246-253

18 Chen Z L. Application of zebrafish in drug screens for active ingredients (in Chinese). China J Chin Mater Med, 2015, 40: 1235-1239 [陈志亮. 玟 马鱼在药物篎选中的应用. 中国中药杂志, 2015, 40: 1235-1239] 
19 Tan W P, Lu H Q, Wang X T, et al. Application of zebrafish model in virus research (in Chinese). Med Recapitul, 2020, 26: 1673-1678 [谈文盼, 卢欢倩, 王晓桐, 等. 斑马鱼模型在病毒研究中的应用. 医学综述, 2020, 26: 1673-1678]

20 Richardson R, Slanchev K, Kraus C, et al. Adult zebrafish as a model system for cutaneous wound-healing research. J Invest Dermatol, 2013, 133: $1655-1665$

21 Mathias J R, Dodd M E, Walters K B, et al. Characterization of zebrafish larval inflammatory macrophages. Dev Comp Immunol, 2009, 33: 12121217

22 Renshaw S A, Loynes C A, Elworthy S, et al. Modeling inflammation in the zebrafish: How a fish can help us understand lung disease. Exp Lung Res, 2007, 33: 549-554

23 Progatzky F, Cook H T, Lamb J R, et al. Mucosal inflammation at the respiratory interface: A zebrafish model. Am J Physiol-Lung Cell Mol Physiol, 2016, 310: L551-L561

24 Liu L, Fokkink R, Koelmans A A. Sorption of polycyclic aromatic hydrocarbons to polystyrene nanoplastic. Environ Toxicol Chem, 2016, 35: $1650-1655$

25 Boshtam M, Asgary S, Kouhpayeh S, et al. Aptamers against pro- and anti-inflammatory cytokines: A review. Inflammation, 2017, 40: 340-349

26 van der Aa L M, Chadzinska M, Tijhaar E, et al. CXCL8 chemokines in teleost fish: Two lineages with distinct expression profiles during early phases of inflammation. PLoS One, 2010, 5: e12384

27 van der Aa L M, Chadzinska M, Golbach L A, et al. Pro-inflammatory functions of carp CXCL8-like and CXCb chemokines. Dev Comp Immunol, 2012, 36: 741-750

28 Raghuwanshi S K, Su Y, Singh V, et al. The chemokine receptors CXCR1 and CXCR2 couple to distinct G protein-coupled receptor kinases to mediate and regulate leukocyte functions. J Immunol, 2012, 189: 2824-2832

29 Viola A, Luster A D. Chemokines and their receptors: Drug targets in immunity and inflammation. Annu Rev Pharmacol Toxicol, 2008, 48: 171197

30 Harada A, Sekido N, Akahoshi T, et al. Essential involvement of interleukin-8 (IL-8) in acute inflammation. J Leukoc Biol, 1994, 56: 559-564

31 Kobayashi Y. The role of chemokines in neutrophil biology. Front Biosci, 2008, 13: 2400-2407

32 Tanaka T, Narazaki M, Kishimoto T. IL-6 in inflammation, immunity, and disease. Cold Spring Harb Perspect Biol, 2014, 6: a016295

33 Barton S J, Ngo S, Costello P, et al. DNA methylation of Th2 lineage determination genes at birth is associated with allergic outcomes in childhood. Clin Exp Allergy, 2017, 47: 1599-1608

34 Dris R, Gasperi J, Mirande C, et al. A first overview of textile fibers, including microplastics, in indoor and outdoor environments. Environ Pollut, 2017, 221: 453-458 


\title{
Co-exposure to different sized polystyrene microplastics and benzo[a]pyrene affected inflammation in zebrafish and bronchial-associated cells
}

\author{
Yawen $\mathrm{Xu}$, Jun Zhu, Jinye Hu, Zhan Zhang, Lei Li \& Qian Wu* \\ Department of Health Inspection and Quarantine, School of Public Health, Nanjing Medical University, Nanjing 211166, China \\ * Corresponding author, E-mail: wuqian@njmu.edu.cn
}

In recent years, emerging research has revealed that microplastics (MPs) can pollute the air. Cellulose and plastic fibers have been found in the lungs of patients with lung cancer, indicating that MPs can "travel" through the atmosphere into the respiratory tract. Due to the hydrophobicity and relatively large surface area of MPs, the biotoxicity of MPs is greatly enhanced by their adsorption and enrichment in persistent organic pollutants (POPs). With the rapid development of the economy, emissions from coal burning and automobile exhaust have made polycyclic aromatic hydrocarbon (PAHs) one of the key pollutants in urban air that cannot be ignored. Epidemiological studies have shown that PAH exposure is associated with the development of respiratory diseases, such as bronchitis and asthma, in children. The aim of this study was to investigate the inflammatory effects of co-exposure to different size polystyrene MPs (PS-MPs) and benzo[a]pyrene (BaP) on adult zebrafish gills and bronchial-related cells to provide basic information for assessment of the potential health risks of combined exposure to the human respiratory system. PS-MPs (with size of 0.5 and $5 \mu \mathrm{m}$ ) and BaP were co-administered to embryos for $7 \mathrm{~d}$, adult zebrafish for $14 \mathrm{~d}$, and HBE cells and HBMSCs for $48 \mathrm{~h}$. The relative expression levels of inflammatory cytokine genes in the different exposure groups were determined by real-time polymerase chain reaction (PCR). The ingestion of microplastics into fish bodies and cells was observed by stereoscope and confocal microscopy, respectively. Result shows that microplastics of two sizes could be ingested by zebrafish embryos. When exposed only to $0.5-\mu \mathrm{m}$ PS-MPs, relative expression of the $T N F-\alpha, I L-6$, and $I L-8$ genes was significantly increased compared with that in the control; relative expression of the IFN- $\gamma$ gene was largely increased in the gills of zebrafish in 5- $\mu \mathrm{m}$ PS-MP-exposed group. Moreover, relative expression of the $I F N-\gamma, I L-6$ and $I L-8$ genes in the group co-exposed to BaP and 0.5- $\mu \mathrm{m}$ PS-MPs was higher than that in BaP group. In addition, $0.5-\mu \mathrm{m}$ PS-MPs could be ingested by both cell lines. Upon exposure to 0.5$\mu \mathrm{m}$ PS-MPs alone, relative expression of genes $T N F-\alpha, I L-6$, and $I L-8$ was considerably increased compared with that in the control HBE cells. In HBSMCs, upon exposure to $0.5-\mu \mathrm{m}$ PS-MPs alone, relative expression of the $T N F-\alpha, I L-8$, and $I L-1 \beta$ genes was substantially increased compared with that in the control group. Compared with that following exposure to $\mathrm{BaP}$ alone, relative expression of the $I F N-\gamma$ and $I L-6$ genes in HBSMCs in $0.5-\mu \mathrm{m}$ PS-MPs and BaP co-exposure group was remarkably increased, indicating a possible combined effect; however, co-exposure of 5- $\mu \mathrm{m}$ PS-MPs and BaP weakened the proinflammatory function of $\mathrm{BaP}$ and especially influenced relative expression of the $T N F-\alpha$ and $I L-8$ genes. In addition, none of the co-exposure groups of HBE cells showed obvious combined effects. The corollary is that particle size may affect the ingestion of PS-MPs in cells. In addition, the size-dependent effects of PS-MPs influence the accumulation of organic pollutants and their biotoxicity.

polystyrene microplastics, benzo(a)pyrene, inflammation, zebrafish, cell doi: 10.1360/TB-2020-0668 